\title{
PENDIDIKAN MEWUJUDKAN GENERASI BERKARAKTER
}

\author{
Juhri Abdul Mu'in \\ FKIP, Universitas Muhammadiyah Pringsewu Lampung \\ juhriabdul@umpri.ac.id
}

\begin{abstract}
The character of education is a system of instilling character values to students which includes components of knowledge, awareness or willingness, and action. The implementation of these values, among others, is good to God Almighty, yourself and fellow humans. The process can be pursued through the character education such as curriculum content, learning processes, and assessments, quality of relationships, handling or management of subjects, school management, implementing extracurricular activities, empowering infrastructure, financing education, and cooperation of all citizens and school environment collaboratively and systemically.
\end{abstract}

Keywords : character education

\section{PENDAHULUAN}

Persoalan pendidikan berkarakter masih saja menjadi sorotan tajam dalam dunia pendidikan kita, baik itu melalui media cetak, wawancara, dialog dan lain sebagainya. Berbagai alternatif penyelesaian permasalahan ini telah dilakukan antara lain dengan berbagai regulasi dan/atau peraturan perundang-undangan dari sistem pendidikan nasional (Sisdiknas), sampai pada peraturan Presiden (Perpres), peraturan pemerintah, peraturan menteri, dan peraturan daerah (perda). Namun, semuanya itu belum juga mengatasi permasalahan pendidikan berkarakter.

Hasil dari kajian empirik di lapangan diperoleh temuan antara lain permasalahan pendidikan berkarakter yang belum menunjukkan hasil yang signifikan. Hal tersebut disebabkan oleh berbagai hal antara lain, 1) Rendahnya pemahaman guru terhadap implementasi pendidikan karakter. Hal ini ditunjukkan dengan adanya sebagian besar pendidik yang belum mampu membedakan konsep karakter dan kepribadian, belum memahami pentingnya pendidikan karakter, serta rendahnya pemahaman tentang nilai-nilai karakter yang perlu ditanamkan kepada peserta didik. 2) Belum berhasilnya guru dalam menanamkan pendidikan karakter bagi peserta didik yaitu guru belum memahami prinsip-prinsip pendidikan karakter, belum menerapkan peran sebagai pembentuk karakter, belum mampu mengatasi adanya penyimpangan perilaku karakter peserta didik, dan belum menerapkan pendidikan karakter secara efektif. 
Pendidikan berkarakter sebenarnya bukan merupakan hal yang baru. Bahkan sejak awal kemerdekaan Republik Indonesia, masa orde lama, masa orde baru, dan bahkan dimasa pasca reformasi sudah dilakukan pendidikan karakter ini dengan nama dan bentuk yang beragam. Di era pasca reformasi misalnya dimulai tahun 2002 rencana perubahan Kurikulum Betbasis Kompetensi (KBK-Try Out), tahun 2004 dengan KTSP, dan di tahun 2014 dengan K-13 nya lebih perubahan kurikulum ini sebenarnya lebih menekankan pada lulusan hasil pendidikan yang berkarakter.

Situasi sosial, kultural masyarakat kita akhir-akhir ini memang semakin mengkhawatirkan. Adanya berbagai macam peristiwa dalam pendidikan yang semakin merendahkan harkat dan martabat manusia. Hancurnya nilai-nilai moral, merebaknya ketidakadilan, menjamurnya kasus korupsi, terkikisnya rasa solidaritas telah terjadi dalam dunia pendidikan kita. Rupanya usaha perbaikan di bidang pendidikan dirasa tidak hanya cukup dengan perbaikan sarana dan prasarana pendidikan saja, melainkan membutuhkan perencanaan kurikulum yang sangat matang yang sesuai dengan kondisi dan kebutuhan bangsa. Bukan sekedar perancanaan kurikulum yang matang, namun peran tenaga pemndidik profesional dalam pelaksanaan proses pembelajaran yang berkualitas menjadi salah satu kunci penting pembentukan karakter peserta didik. Kita sadari hingga saat ini belum mampu menunjukkan hasil pendidikan karakter yang optimal. Hal ini ditandai adanya fenomena sosial yang ditunjukkan perilaku yang tidak berkarakter.

Kita pahami bersama bahwa dalam Undang-undang No. 20 tahun 2003 tentang Sistem pendidikan Naional telah ditegaskan bahwa:

"Pendidikan nasional berfungsi mengembangkan kemampuan dan membentuk watak serta peradaban bangsa yang bermartabat dalam rangka mencerdaskan kehidupan bangsa, bertujuan untuk berkembangnya potensi peserta didik agar menjadi manusia yang beriman dan bertakwa kepada Tuhan Yang Maha Esa, berakhlak mulia, sehat, berilmu, cakap, kreatif, mandiri, dan menjadi warga negara yang demokratis serta bertanggung jawab."

Upaya pendidikan yang dilakukan oleh lembaga pendidikan dan institusi pembina pendidikan lain belum sepenuhnya mengarahkan dan mencurahkan perhatian 
secara komprehensif pada upaya pencapaian tujuan pendidikan nasional. Dalam konteks ini diperlukan adanya penerapan hukum yang lebih kuat, tegas, dan objektif.

\section{PEMBAHASAN}

Dalam rangka mewujudkan generasi terampil bekerja di era Revolusi 4.0 terdapat beberapa pertanyaan mendasar yang perlu dijawab melalui tindakan nyata dalam pelaksanaan pendidikan berkarakter sebagai berikut ini:

1. Bagaimanakah memahami konsep pendidikan Karakter bagi pendidik profesional?

2. Sudahkah pendidik memahami perbedaan konsep karakter dengan kepribadian?

3. Apakah pendidik telah memahami secara singkat sejarah ttentang munculnya pendidikan karakter?

4. Apakah pendidik sudah memahami nilai-nilai pendidikan karakter yang perlu diajarkan dan ditumbuhkembangkan kepada peserta didik?

5. Apakah pendidik telah memahami dan/atau menerapkan prinsip-prinsip pendidikan karakter dalam proses pembelajaran?

6. Apakah pendidik telah menerapkan peran pendidik dalam pembentukan karakter peserta didik?

7. Apakah pendidik telah memahami dan mampu mengatasi penyimpangan perilaku karakter peserta didik yang diajar?

8. Apakah pendidik sudah berusaha meneraspkasn pendidikan karater yang efektif dalam proses pembelajaran?

Tugas kita sebagai pendidik profesional adalah bagaimana mampu memberikan jawaban terhadap pertanyaan tersebut di atas melalui implementasi pendidikan karakter dalam proses pembelajaran. Sehingga pendidikan berkarakter yang kita selenggarakan dapat mewujudkan generasi yang memiliki keterampilan kerja. Tulisan ini secara sederhana dapat dijadikan sebagai acuan untuk memahami dan mengimplementasikan pendidikan berkarakter secara teoritik maupun empirik.

\section{A. Konsep Dasar Pendidikan Karakter}

Makna pendidikan karakter adalah suatu sistem penanaman nilai-nilai karakter kepada peserta didik sekolah yang meliputi komponen pengetahuan, 
kesadaran atau kemauan, dan tindakan". Pelaksanakan nilai-nilai tersebut, baik terhadap Tuhan Yang Maha Esa, diri sendiri, dan sesama manusia, dapat ditempuh melalui proses pendidikan karakter di sekolah yang melibatkan semua komponen pendidikan seperti isi kurikulum, proses pembelajaran, dan penilaian, kualitas hubungan, penanganan atau pengelolaan mata pelajaran, pengelolaan sekolah, pelaksanaan aktivitas atau kegiatan ekstrakurikuler, pemberdayaan sarana prasarana, pembiayaan pendidikan, dan kerja sama seluruh warga dan lingkungan sekolah secara kolaboratif dan sistemik.

Pemahaman konsep tentang pendidikan karakter dapat dijadikan rujukan pemahaman dan wawasan pengetahuan lain tentang pendidikan berkarakter. Lickona (2015) menyatakan bahwa pendidikan karakter adalah suatu usaha yang disengaja untuk membantu seseorang (peserta didik) sehingga ia dapat memahami, memperhatikan, dan melakukan nilai-nilai etika yang inti. Kemudian menurut Suyanto (2016), ia menyatakan bahwa: "pendidikan karakter yaitu cara berpikir dan berperilaku yang menjadi ciri khas tiap individu untuk hidup dan bekerja sama, baik dalam lingkup keluarga, masyarakat, bangsa, maupun negara".

Kedua pendapat para pakar tersebut mengilustrasikan bahwa karakter digambarkan cara berpikir, mengucapkan suatu ucapan, dan tindakan atau perilaku seseorang. Dalam konteks ini yang dimaksud adalah cara berpikir, mengucapkan suatu ucapan, dan tindakan atau perilaku peserta didik yang tidak bertentangan dengan nilai-nilai kehidupan bermasyarakat, bernegara, dan berbangsa. Sebagai bangsa yang menjunjung tinggi falsafah Pancasila sebagai filosifi bangsa dan Undang-Undang Dasar 1945 sebagai dasar konstitusi negera dan bangsa Indonesia.

\section{B. Perbedaan Karakter dan Kepribadian}

Konsep kepribadian dapat dijelaskan bahwa: kepribadian adalah "kodrat dari Tuhan Sang Pencipta alam semesta. Kepribadian setiap manusia yang dilahirkan dikodratkan memiliki kepribadian pasti”. Namun dalam perilakunya ada kelemahan dan kelebihan di berbagai aspek kehidupan bermasyarakat, berbangsa, dan bernegara. Setiap manusia yang dilahirkan diberikan kodrat masing-masing pribadi yang unik dan cenderung berbeda-beda, baik dalam berfikir, mengucapkan sesuatu, dan melakukan tindakan menggambarkan 
kepribadiannya yang di kodratkan Tuhan pencipta. Konsep kepribadian manusia secara umum dapat dikelompokkan menjadi 4 tipe, yaitu:

1. Koleris: tipe ini bercirikan pribadi yang suka kemandirian, tegas, berapi-api, suka tantangan, dan mudah bosan atas dirinya sendiri biasa dikatakan kurang konsisten dengan pikirran, ucapan, dan tindakannya.

2. Sanguinis: peserta didik dengan tipe ini bercirikan suka dengan hal yang bersifat praktis, selalu happy dan ceria selalu, suka kejutan baru, suka sekali dengan kegiatan social, dan bersenang-senang.

3. Phlegmatis: tipe ini pesrta didik bercirikan suka bekerjasama dengan teman sejawat, suka menghindari konflik, tidak suka perubahan yang bersifat mendadak, suka memilih teman bicara yang enak, dan menyukai hal yang pasti.

4. Melankolis: peserta didik yang memiliki tipe ini bercirikan suka dengan hal detil, mampu menyimpan kemarahan, melaakukan kegiatan yang cenderung sempurna (perfection), suka instruksi yang jelas, kegiatan rutin sangat disukai, dan suka menyelesaiakan kegiatan yang disukai.

\section{Sejarah Munculnya Pendidikan Karakter}

Pendidikan Karakter dipakai secara khusus dalam konteks pendidikan, dan baru muncul pada akhir abd ke-18. Pertama kalinya dicetuskan oleh seorang ahli dalam bidang pendidikan (Pedadog) Jerman F.W Foerster. Terminologi ini mengacu pada sebuah pendekatan idealis-spiritualis dalam pendidikan yang juga dikenal dengan teori Pendidikan Normatif. Pendapat ini kemudian menjadi prioritas ialah nilai-nilai teransenden yang dipercaya sebagai motor penggerak sejarah timbulnya pendidikan karakter, baik individu maupun bagi sebuah perubahan sosial. Namun, sebenarnya pendidikan karakter telah lama menjadi bagian inti sejarah pandidikan itu sendiri. Secara jujur pendidikan di Lembaga Pendidikan dan tenaga Kependidikan seperti di FKIP, STKIP, dan lembaga pendidikan lainnya tidak ditemukan lagi materi pelajaran sejarah pendidikan.

Lahirnya Pendidikan Karakter bisa dikatakan sebagai sebuah usaha untuk menghidupkan kembali pedagogi ideal-spiritual yang sempat hilang oleh pendidikan yang menekankan pendidikan positivme yang dipelopori oleh filsuf 
Perancis Auguste Comte yang berpendapat pendidikan yang dilaksanakan positif mampu menghasilkan perilaku peserta didik yang positif. Foerster menolak gagasan yang meredusir pengalaman manusia pada sekedar bentuk murni hidup alamiah. Gambaran sekilas ini harus dijadikan pemahaman sekilas tentang pentingnya pendidik memiliki pengetahuan tentang sejarah pendidikan karakter.

\section{Nilai-Nilai dalam Pendidikan Karakter}

Pada hakikatnya kita sudah mengenali tentang nilai-nilai karakter yang harus dimiliki peserta didik setelah mengikuti proses pembelajaran di kelas oleh guru profesonal. Pemahaman dan penerapan nilai-nilai karakter ini, sekurangkurangnya harus dipamahi lalu diterapkan dalam proses pembelajaran di kelas, sedikitnya ada 18 butir nilai-nilai pendidikan karakter yaitu: religius, jujur, toleransi, disiplin, kerja keras, kreatif, mandiri, demokratis, rasa ingin tahu, semangat kebangsaan, cinta tanah air, menghargai prestasi, bersahabat/komunikatif, cinta damai, gemar membaca, peduli lingkungan, peduli sosial, dan tanggung jawab.

Nilai-nilai karakter ini harus dimiliki, dipahami, dan dimplementasikan selama proses pembelajaran berlangsung. Setiap pendidik yang merasakan dirinya sebagai pendidik profesional, yang ditandai dengan kepemilikan kompetensi pedagogik, personaliti, sosial, dan kompetensi profesional. Harus mampu mengimplementasikan kompetensi tersebut secara efektif selama dalam proses pembelajaran berlangsung. Jika setiap pendidik telah mampu mengimplementasikan kompetensinya, dapat dijamin lulusan pendidikan berkualitas yang pada giliran memi8liki keterampilan kerja unggul.

\section{E. Prinsip Pendidikan Karakter}

Setiap pendidik dalam melaksanakan tugasnya, perlu memahami dan menerapkan berbagai prinsip pendidikan karakter. Lembaga "Character Education Quality Standards" merekomendaikan sekurang-kurangnya ada enam prinsip yang harus diterapkan oleh pendidik dalam me;laksanakan proses pembelajaran untuk mewujudkan pendidikan karakter yang efektif, sebagai berikut 
1. Mempromosikan dalam arti menjelaskan dan memberikan keteladanan tentang nilai-nilai dasar etika (tatanan baik-buruk) sebagai basis karakter kepada peserta didik setiap saat.

2. Mengidentifikasikan nilai-nilai karakter secara komprehensif yang dikelompokkan ke ranah: pengetahuan (knowledge), sikap (attitude), dan keterampilan kerja (psickomotor), dengan kata lain meningkatkan kemampuan berfikir, mengelola sikap (perasaan), dan dan menekankan pada aspek perilaku, dalam bentuk keterampilan berkarya (kerja).

3. Mengguanakan pendekatan yang tepat, proaktif, dan efektif untuk membangun dan menumbuhkan nilai-nilai karakter.

4. Menciptakan komunitas sekolah yang memiliki kepedulian yang menjunjung nilai-nilai etika dan akhlaqul karimah sebagaiman mana amanat dalam UU Sisdiknas.

5. Memberi kesempatan kepada peserta didik untuk menunjukkan perilaku yang baik dan menjunjung norma yang berlaku di masyarakat.

6. Memiliki cakupan terhadap kurikulum yang bermakna dan menantang yang menghargai semua peserta didik, membangun karakter mereka dan membantu mereka untuk lebih sukses di masa mendatang.

\section{F. Peran Pendidik dalam Membentuk Karakter}

Sesungguhnya tugas pendidik sangat kompleks. Selain mengajar dan mendidik peserta didiknya, prilaku dan tingkah laku pendidik secara langsung atau tidak langsung akan ditiru oleh peserta didiknya. Perilaku pendidik yang menjunjung tinggi nilai dan norma-norma ini akan membentuk karakter peserta didik yang di ajar. Perilaku pendidik yang dapat diteladani peserta didiknya antara lain adalah: pendidik datang tepat waktu, pendidik mengucapkan salam dengan ramah kepada siswa ketika memasuki ruang kelas; mengajak berdoa sebelum membuka dan menutup pelajaran; mengecek kehadiran peserta didik sebelum memulai pelajaran; mendoakan siswa yang tidak hadir karena sakit atau karena halangan lainnya; memastikan bahwa setiap peserta didik datang tepat waktu; dan menegur peserta didik yang terlambat dengan sopan.

Jika setiap guru mampu memainkan perannya tersebu sebagai upaya untuk menumbuhkan dan membangun perilaku peserta didik yang menunjukkan 
tindakan terpuji. Peserta didik akan terbiasa berfikir, mengucapkan sesuatu, dan melakukan berbagai tindakan akan mencerminkan akhlaqul karimah.

\section{G. Penyimpangan Karakter pada Peserta Didik}

Meskipun pendidik telah mengajarkan nilai-nilai karakter yang baik kepada peserta didiknya, kadangkala peserta didik tidak menuruti atau tidak mematuhi nilai karakter tersebut sebagaimana yang telah diteladankan oleh pendidik selama dalam pelaksanaan pembelajaran. Beberapa contoh berikut merupakan gambaran peserta didik yang berkarakter rendah, misal: Siswa tidak jujur ketika mengerjakan soal ujian; tidak disiplin ketika mengikuti upacara bendera (tidak memakai atribut yang lengkap); tidak bertanggung jawab terhadap kesalahan; bertengkar karena suatu permasalahan (merupakan contoh siswa yang tidak cinta damai)

\section{H. Pendidikan Karakter yang Berhasil}

Keberhasilan program pendidikan karakter dapat diketahui melalui pencapaian indikator oleh peserta didik sebagaimana tercantum dalam Standar Kompetensi Lulusan Sekolah Menengah Pertama (SMP), yang antara lain meliputi tindakan sebagai berikut:

1. Mengamalkan ajaran agama yang dianut sesuai dengan tahap perkembangan remaja.

2. Memahami kekurangan dan kelebihan diri sendiri.

3. Mematuhi aturan-aturan sosial yang berlaku dalam lingkungan yang lebih luas.

4. Menghargai keberagaman agama, budaya, suku, ras, dan golongan sosial ekonomi dalam lingkup nasional.

5. Menunjukkan sikap percaya diri.

6. Mencari dan menerapkan informasi dari lingkungan sekitar dan sumbersumber lain secara logis, kritis, dan kreatif.

7. Menunjukkan kemampuan berpikir logis, kritis, kreatif, dan inovatif.

8. Menunjukkan kemampuan belajar secara mandiri sesuai dengan potensi yang dimilikinya.

Pada tataran sekolah, kriteria pencapaian pendidikan karakter adalah terbentuknya budaya sekolah, yaitu perilaku, tradisi, kebiasaan keseharian, dan 


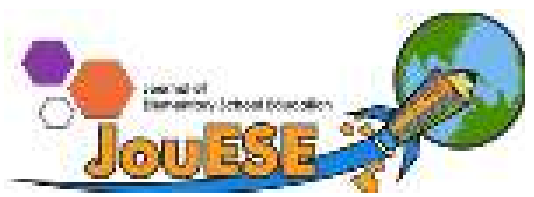

simbol-simbol yang dipraktikkan oleh semua warga sekolah, dan masyarakat sekitar sekolah harus berlandaskan nilai-nilai tersebut.

\section{PENUTUP}

Penyelenggaraan pendidikan kita telah berusaha untuk meningkatkan kesesuaian dan mutu pendidikan karakter melalui sekolah-sekolah, terutama Sekolah Menengah Pertama (SMP). Anak usia SMP sangat cocok untuk diberi pembelajaran tentang pendidikan karakter. Pendidik adalah orang tua para peserta didik yang memiliki tugas utama menanamkan nilai-nilI moral dan norma yang berlaku di masyarakat. Pendidikan karakter bertujuan untuk meningkatkan mutu penyelenggaraan dan hasil pendidikan di sekolah yang mengarah pada pencapaian pembentukan karakter dan akhlak mulia bagi peserta didik secara utuh, terpadu, dan seimbang. Bila pendidikan karakter telah mencapai keberhasilan, tidak diragukan lagi kalau masa depan bangsa Indonesia ini akan mengalami perubahan menuju kejayaan. Bila pendidikan karakter ini mengalami kegagalan sudah pasti dampaknya akan sangat besar bagi bangsa ini. Negara kita akan semakin ketinggalan dari negara-negara lain.

\section{DAFTAR PUSTAKA}

Ahmad Muhaimin. (2011). Urgensi Pendidikan Karakter di Indonesia. Jakarta: Diterbitkan oleh: Ar-Ruzz Mwndia.

Juhri AM. (2018) Profesi Kependidikan dan Bimbingan Konseling. Metro: penerbit VC. Laduni lifatama

(2016) Supervisi Pendidikan. Metro: Penerbit VC. Laduni lifatama

(2015) Landasan dan Wawasan Pendidikan Suatu pendekatan kompetensi guru. Metro: Penerbit VC. Laduni Lifatama

http://educasikompasiana.com/2011/03/29/mengapa-integritas-gurubegitu-lemah.

http://suarakomunitas.net/baca/13732/membangun-pendidikan-berkarakter.html.

http://wijayalabs.wordpress.com/2009/12/11/pendidikan-berkarakter.

Undang-Undang Republik Indonesia No.20 tahun 2003 tentang Sistem Pendidikan Nasional. 